\title{
Voltaire sobre Shakespeare e Newton ou o gênio e o gosto nas artes e ciências
}

\author{
Rodrigo Brandão
}

UFPR 

Na décima quarta carta das Cartas Filosóficas, intitulada "Sobre Descartes e Newton”, acompanhamos um francês do século XVIII se deparando com outro mundo ao desembarcar na Inglaterra: o formato da Terra, o vazio, a luz, a rotação terrestre e o fenômeno das marés não são os mesmos nos dois países. Voltaire, jogando com aquilo que tinha se transformado de contenda científica em querela nacional e disputas de gerações no interior da Academia de Ciências de Paris ${ }^{1}$, mistura a oposição das teses científicas cartesianas e newtonianas com uma oposição mais profunda entre a França e a Inglaterra. Em outros termos, o elogio da ilha e a crítica da terra natal não se encerram na oposição entre filosofias da natureza conflitantes: o sistema político, o lugar e reconhecimento do artista e do cientista, a liberdade de expressão e de religião, tudo parece evidenciar a superioridade da Inglaterra em relação à França. $\mathrm{O}$ atraso francês se manifesta sobretudo na presença de um pensamento teológico que contamina a história e a moral: eis o sentido da vigésima quinta carta sobre Pascal, texto aparentemente estranho a um conjunto inicialmente intitulado Cartas Inglesas. Arrancar a pele de Pascal é fazer sangrar o cristianismo, cuja força na sociedade francesa aparecia a Voltaire como obstáculo para o avanço da liberdade.

Mesmo a oposição entre Descartes e Newton não se limita às teses conflitantes de suas teorias científicas: a terra de Descartes é um lugar de fanáticos, que o filósofo, assim como o autor das cartas, teve de abandonar para fugir das perseguições. Newton, ao contrário, já nasceu num lugar e num tempo de liberdade, suas investigações científicas não foram condenadas, nem seu autor teve de levar uma vida atribulada por fugas e pela intolerância que vivem os franceses (Voltaire, 1973, p. 2930). Como compreender essa mistura feita por Voltaire entre a oposição das teses físicas de Descartes e Newton e a oposição

1 Cf. Badinter, 2007. 
entre as vidas dos dois filósofos e os costumes de seus respectivos países? Para Voltaire, a teoria da gravitação só poderia surgir na Inglaterra, pois lá havia uma atmosfera de liberdade e de reconhecimento das ciências que a França não possuía. O romance do cartesianismo não é apenas fruto da excentricidade ou da imaginação insuflada de seu autor; a hipertrofia imaginativa dos filósofos de sistema do XVII é resultado de sua insularidade, da imaginação sem comunicação, do isolamento intelectual, por assim dizer. Para que compreendamos o avanço que significa a física newtoniana é preciso, portanto, reconhecer a diferença entre os costumes da Inglaterra e da França, entre o fanatismo de um tempo e a liberdade e tolerância de outro. Numa época e num país de perseguições e intolerância, de contendas violentas, o resultado teórico só poderá ser o dogmatismo da filosofia de sistema, a imaginação sem a comunicação se perde. Ora, Voltaire faz aqui um movimento que não é sem interesse, ele estabelece um elo entre as teorias científicas de Descartes e Newton, e, mais importante, entre as maneiras distintas de proceder filosoficamente, e os costumes das sociedades inglesa e francesa, realizando aquilo que alguns chamaram de uma protosociologia das ciências (Martin-Haag, 2002, p. 18 e ss.). Em outras palavras, seu procedimento histórico de consideração dos sistemas filosóficos, desenvolvido em obras posteriores como os Elementos da Filosofia de Newton e o quase desconhecido Des singularités de la nature, permitiria cercar com mais precisão o terreno no qual frutificam as diversas teorias científicas.

Portanto, a crítica a Descartes e o elogio a Newton não são ingênuas. Mesmo que ainda fruto de um neófito, os estudos tardios de ciência e da física newtoniana realizados em parceria com Mademe du Châtelet, cientista talentosa, tradutora dos Principia de Newton e das Fábulas das abelhas de Mandeville, bem como o desenvolvimento de seus estudos históricos corroboram e aprofundam a intuição inicial das Cartas filosóficas: a 
dependência do avanço das ciências e das artes do desenvolvimento da sociedade e da ampliação da liberdade².

Em outras palavras, a superioridade da ciência inglesa não se explica por meio do recurso à genialidade de um cientista, genialidade ela mesma inexplicável ${ }^{3}$. Na verdade, quem é descrito repetidas vezes como gênio é Descartes, não Newton. Do outro lado, a inferioridade da ciência cartesiana não se explica somente pela imaginação romanesca de seu autor. Aliás, é justamente essa genialidade como excesso de imaginação, como imaginação sem regras, que deveríamos explorar para captar o verdadeiro sentido da oposição entre a grandeza da ciência inglesa e o romance do cartesianismo.

Contudo, a superioridade da Inglaterra tem um limite. Se nas ciências e no sistema político os ingleses parecem ter algo a ensinar aos franceses, este não parece ser o caso para as artes. Neste campo os franceses não precisam dos modelos estrangeiros. É certo que os ingleses aqui, juntamente com os espanhóis, são também pioneiros. ${ }^{4}$ Shakespeare é, segundo Voltaire, o criador do teatro inglês. Mas como todo criador, como toda inovação e originalidade que se encontram no início das artes, ele tem um valor ambíguo: ele é forte e fecundo, mas sem "bom gosto".

[Shakespeare] tinha um gênio cheio de força e de fecundidade, natural e

2 Esta dependência, no entanto, está longe de ser encarada de maneira ingênua ou otimista. Ao contrário, em Des singularités de la nature, Voltaire constata a dificuldade dessa relação, que não é de causa e efeito e vê em sua época apenas um crepúsculo das luzes, tendo em vista o fosso que separa o avanço das ciências e o avanço da sociedade. Cf. Des singularités de la nature. Oeuvres complètes de Voltaire, éd. Louis Moland. Paris: Garnier, $1877^{-1885}$, tome 27, p. 125-191.a

3 Não se explica completamente deveríamos dizer, pois na vigésima quarta carta das Cartas Filosóficas, Sobre as Academias, carta na qual Voltaire atribui a Newton o adjetivo "gênio", o francês constata que as academias não criaram Newton, e que as descobertas devem também algo ao acaso e ao gênio individual.

4 "Os ingleses (e também os espanhóis) já possuíam um teatro na época em que os franceses só possuíam tablados. Shakespeare, considerado o Corneille inglês, florescia mais ou menos na mesma ocasião em que Lope de Vega. Criou o teatro" (Voltaire, 1973, 39). 
sublime, sem a menor chama de bom gosto e sem o menor conhecimento das regras (Voltaire, 1973, 39).

E no prefácio da edição de 1736 de a Morte de César, Voltaire diz:

Shakespeare, pai da tragédia inglesa, é também pai da barbárie que nela reina. Seu gênio sublime, sem cultura e sem gosto, fez um caos do teatro criado por ele. Suas peças são monstros nas quais se encontram partes que são obras-primas da natureza. Sua tragédia intitulada A Morte de César começa pelo seu triunfo no Capitólio e termina pela Morte de Brutus e de Cassius na batalha de Filipos. César é assassinado em cena. Assiste-se a senadores bancando bufões com a escória do povo. É uma mistura daquilo que a tragédia tem de mais terrível com aquilo que a farça tem de mais baixo.

O natural e a genialidade constituem a grandeza de Shakespeare, mas a fecundidade do gênio é sublime, está acima do comum e, portanto, não observa as regras que organizam a prática de seu gênero. O bom gosto, o respeito às regras, se opõe ao natural do gênio, importante no início das artes, mas desastroso para seu destino. Daí que a própria genialidade de Shakespeare tenha colocado em risco o teatro inglês, pois o natural específico não é passível de imitação.

No rico debate sobre a tensão clássica entre gênio e gosto, Voltaire toma partido da história e do cultivo contra a primazia da imaginação e do natural. É certo, no entanto, que reconhece a importância dos gênios, e que a perfeição artística é atingida com a conjugação de gênio e do gosto - ou o domínio da natureza imaginativa singular do artista pelo cultivo e pela tradição. Contudo, há mesmo em Voltaire uma recusa do recurso ao natural, ao original, que se manifesta em diversas formas: na recusa da categoria de estado de natureza para pensar a política e a história, categoria ridicularizada no poema Le Mondain, na recusa de uma história 
sobre origens (mesmo das histórias muito recuadas no tempo) e também na recusa da expressão direta do natural nas artes.

Nas Lettres d'un voyageur anglais sur la France, 1781-178 -, récit d'une visite faite à Ferney en 1776, o viajante inglês John Moore narra uma pequena história que explicita anedoticamente a recusa da natureza pura por meio da permanente crítica à Shakespeare. Ele diz:

Uma noite, em Ferney, em que se discutia sobre o gênio de Shakespeare, Voltaire declamava contra a impropriedade e absurdo que havia em introduzir na tragédia personagens vulgares e um diálogo baixo e abjeto; ele citava vários exemplos nos quais nosso poeta não havia respeitado esta regra, mesmo nas peças mais tocantes. Um senhor, que era um admirador zeloso de Shakespeare, observou, procurando desculpar nosso célebre compatriota, que, ainda que seus personagens fossem tirados do povo, eles não eram menos naturais. "Com sua permissão, senhor, replicou-lhe Voltaire, minhas nádegas são bem naturais e, no entanto, uso calçasร.

A anedota acima encerra uma lição sobre o classicismo de Voltaire, lição bem explorada por Leo Spitzer em Études de style: o puro natural não deve ser objeto da arte, concebida justamente como o domínio e regramento do natural. Em «Quelques interprétations de Voltaire », Spitzer analisa quatro textos do autor: a tragédia Zaïre, comparando-a com Otelo de Shakespeare, o poema de salão Les Vous et les Tu, um excerto de O Século de Luís XIV, e uma carta a Madame Necker de 19 de junho de 1770. Spitzer tenta mostrar na comparação entre Zaïre e Otelo e do trecho de O Século de Luís XIV com um texto de Bossuet sobre o mesmo episódio o que Voltaire conserva de seus modelos e o que ele inova. ${ }^{6}$ Quanto ao estudo em que compara Zaïre e Otelo, o que é

5 Apud Lagrave, 1995, p. 1246.

6 Não precisamos avaliar aqui a veracidade da afirmação de que Zaire é inspirada em Otelo, como é o caso da interpretação de Spitzer, ou uma imitação dela, como parece 
marcante é o decoro do francês em relação à expressão violenta e direta dos sentimentos do personagem Otelo. Enquanto o diálogo entre Otelo e Desdêmona, no momento em que o personagem principal interpela sua esposa sobre sua suposta traição, expõe um « absoluto humano mais alto que o formalismo do decoro », o mesmo trecho em que dialogam Zaïre e Orosmane revela que"a vida interior individual se insere num quadro formal preestabelecido ». No trecho de Otelo há uma violência dos termos que nada têm a ver com as palavras de Orosmane, marcadas por uma dimensão cortesã ausente na peça do inglês. Nas palavras de Spitzer:

Lá onde Shakespeare dá à força da paixão humana dimensões cosmicas, em metáforas as mais surpreendentes, o francês, com a medida e a atenuação (l'effet de sourdine) da razão, cinde tudo que é vida, criando assim uma linguagem retórica em que o patético é dominado e que subjuga o interlocutor (Spitzer, 1970, 347).

Por um lado, deveríamos conceber essa atitude como a defesa por parte de Voltaire de uma concepção em que a arte, enquanto técnica, se constitui como domínio e regramento da natureza. Cuidado, no entanto, para não contentarmo-nos apenas como já velho mote do domínio violento da natureza. Devemos lembrar que as regras não são estranhas à natureza. Para o pensamento clássico, a natureza é racional, o que significa dizer que todos os seus processos, ou as vias de Deus, seguem a regra da economia dos meios e da pluralidade dos fins: enfim, o mundo é ordenado. Portanto, esse domínio ou regramento não é a imposição de regras

a Thomas R. Lounsbury, em sua obra de 1902, Shakespeare and Voltaire (New York: Charles Scribner's Sons), para compreender a importância do estudo comparativo empreendido por Spitzer. No entanto, cabe dizer que, em artigo já também centenário em que comenta a obra de Lounsbury, E. J. Dubedout mostra convincentemente que a ausência de referência a Shakespeare no prefácio de Zaïre se justifica: Voltaire nada devia ao inglês, ele tinha outros modelos antigos e franceses para se inspirar, e a referência a Shakespeare não se impunha nem pela originalidade nem pela autoridade. Cf. Dubedout et Zaire, 1906, p. 305-16). 
estranhas à própria natureza, ao contrário, é apenas a captação e reconhecimento daquilo que a constitui. Desse modo, o mais interessante não é se contentar em encontrar ainda outra vez no texto de Voltaire a famigerada técnica dominando a inocente natureza, mas reconhecer que Voltaire desqualifica o pretenso acesso à pura natureza. Na arte, qualquer apresentação já artificializa o natural, sua manifesatação não só deve como sempre é histórica.

É a difícil e complexa relação entre o natural e o artificial que Voltaire trata ao refletir sobre o gênio e o gosto. Ele contribui a seu modo para o rico debate sobre as tensões entre gênio e gosto que marcou o pensamento estético moderno, de Addison ou Dubos a Kant e os românticos alemães. No entanto, mais do que apenas compreender a posição de Voltaire no interior do debate, gostaríamos de explorar como Voltaire se utiliza dessas categorias para organizar sua narrativa da história dos saberes. Transferidas do âmbito das artes para as ciências, são estas duas categorias que auxiliam o autor a narrar uma história filosófica da filosofia, a transformar o relato do passado da filosofia de mera doxografia em uma maneira própria de filosofar.

\section{A filosofia e seu tempo: gênio e gosto segundo Voltaire}

«Génie, m. penac. Genius. Est le naturel et inclination d'un chacun» Jean Nicot Thésor de la langue françoise (1606)

As categorias de gênio e gosto nos textos de Voltaire parecem seguir em boa parte as concepções de seu tempo, bem como sua defesa do gosto parece consequência de seu classicismo. No entanto, por meio da análise das noções envolvidas nos termos de gosto e gênio, e dos usos que Voltaire faz delas, compreendemos melhor como a relação entre a natureza e a originalidade, de um lado, e o cultivo e as regras da arte, de outro, permite a ele organizar uma história e mais precisamente uma história dos saberes que, por sua vez, não é sem originalidade. 
O verbete "Gênio" das Questões sobre a Enciclopédiamenciona duas acepções para o termo. ${ }^{7}$ A primeira se refere ao daimon, aos anjos, sentido que o autor tratou no verbete "Anjo" da mesma obra, e aquela que se refere a um "raro talento". Segundo Voltaire, apesar dos romanos não utilizarem o termo genius para se referirem ao "raro talento" e sim o termo ingenium, modernamente utilizamos "indiferentemente a palavra gênio quando falamos do demônio que guardava uma cidade da antiguidade, ou de um maquinista, ou de um músico", enfim, ingenium e genius teriam se fundido nas línguas neolatinas.

No que se refere à habilidade, não é qualquer talento que merece o nome de gênio. Segundo o autor, o que singulariza o talento genial é ser original e inventivo.

É sobretudo a invenção que parecia um dom dos deuses, esse ingenium quasi ingenitum, uma espécie de inspiração divina. Ora, um artista, mesmo que perfeito em seu gênero, se não for inventivo, se não for original,

7 Estas duas acepções são comuns: GÉNIE, subst. masc. Étymol. et Hist. I. 1. 1532 “caractère, tendance naturelle de l'esprit “ (Rabelais, Pantagruel, VI, éd. V. L. Saulnier, pp. 33-34); 1789 péj. avoir le génie de l'inaction (Staël, Lettres jeun., p. 460); 2.1637 "aptitude particulière, accompagnée d'une grande puissance créatrice " (Chapelain, Les Sentiments de l'Académie sur la Tragi-Comédie du Cid ds Z. rom. Philol. t. 66, p. 186); 1697 " homme de génie “ (Bayle, cité par H. Sommer, Génie, Beiträge zur Bedeutungsgeschichte des Wortes d'apr. FEW t. 4, p. 105b); 3. 1641 caractère propre (ici d'un peuple) (Corneille, Cinna, II, 1). II. 1. 1571 " esprit bon ou mauvais qui, dans la croyance des Anciens, présidait à la vie de chaque homme " (Ronsard, Poëmes, L. II, éd. P. Laumonnier, X, 303, 78); d'où 1637 être mythique bon ou mauvais qui influe sur la destinée (Malherbe, Epitre, 41, éd. Ad. Régnier, II, 411 : c'est le fait du bon génie ou d'une vertu divine qui est dans l'homme de bien); 1689 (Mme de Sevigne, Lettres, éd. M. Monmerqué, IX, 144: il assure que vous êtes son bon génie); 2. 1704 sculpt. (Trév.: figures d'enfans aîles, avec des attributs, qui servent dans les ornemens à representer les vertus, et les passions); 3.1791 " être surnaturel doué d'un pouvoir magique “ (Volney, Ruines, p. 305: Le génie du mal Ahrimane, figuré par la constellation du serpent). III. 1. Av. 1708 “ art de fortifier “ (Vauban, Mémoire pour servir d'instruction dans la conduite des sièges ds Fr. mod. t. 17, p. 67); 2.1835 génie militaire (Boucher); 3. id. génie des Ponts et Chaussées (ibid.). Empr. au lat. genius " démon tutélaire qui préside à la conception, donc à la destinée d'un homme "; le sens de " caractère " est attesté dès le lat. du Bas Empire (TLL s.v., VI, 2, 1831). Le sens III est dû à l'infl. de ingénieur*. Centre National de Ressources Textuelles et Lexicales. Disponível em: www.cnrtl.fr/etymologie/Génie. 
não é considerado gênio; ele passará apenas como um inspirado pelos artistas seus predecessores, mesmo sendo superior a eles (Voltaire, 1771, p. 254).

O duplo sentido do termo gênio não é, portanto, fortuito: o gênio como o inspirado, como o detentor de um dom divino, traz consigo o mesmo apelo ao sobrenatural e ao incompreensível presente em seu sentido primeiro, quando se refere ao demônio pessoal. ${ }^{8} \mathrm{O}$ artista gênio é o inovador, cujo dom divino o torna superior àqueles que apesar de excelentes em seus gêneros não são dotados de originalidade. O gênio marca, assim, uma ruptura com seus predecessores - ele é criador.

Para Voltaire, Descartes é gênio. Ao invés de continuar uma tradição, ele rompeu com ela; criou um novo modo de raciocinar e revelou os erros da antiguidade substituindo-os pelos seus prórios. Sua originalidade e singularidade conferem sua genialidade, mas são também a causa de sua má física.

O gênio é original, porém não é o melhor em sua arte9. Ele se destaca pela invenção, pela criação, por sua imaginação singular, ao invés de se inspirar em seus predecessores, o gênio o é por natureza. O gênio é precisamente o elemento específico, daí ser aplicado também para aquilo que diferencia um povo e uma língua. Essa diferença se manifesta na independência e distância em relação àqueles que praticam as artes; a genialidade, enfim, permite a criação sem mestres, por isso os gênios são costumeiramente os criadores de um gênero, como Shakespeare é dito criador do teatro inglês ${ }^{10}$.

Condensando a oposição entre uma individualidade inde-

8 Sobre a união dos dois sentidos do termo "gênio", ver Martin-Haag, 2002, p. 19.

9 "É possível que muitas pessoas joguem melhor xadrez que o inventor desse jogo [...]" (Voltaire, 1771, 255).

10 "Poussin já era um grande pintor antes de ter visto bons quadros, ele possuía o gênio da pintura. Lulli, que não conheceu nenhum bom músico na França, possuía o gênio da música" (Ibid., 255). 
pendente e isolada, que por isso mesmo é ambígua, e um comum que depende dos mestres e do cultivo, entre a criatividade isolada e a tradição comunicada nas artes, Voltaire afirma:

O gênio conduzido pelo gosto não cometerá jamais erros grosseiros: como Racine desde Andrômaca, Poussin, Rameau, que jamais cometeram um. O gênio sem o gosto cometerá enormes; e ainda pior, ele não será capaz de percebê-los (Voltaire, 1771, 257-8).

A perfeição artística exige que a inventividade natural do gênio seja domada pelas regras do gosto, que a história limite a natureza. Sem um dom natural o artista é considerado mero imitador, sem o hábito conferido pela respeito à tradição, a imaginação se desgarra. A originalidade e inventividade do gênio são indispensáveis no início das artes, mas é precisamente a originalidade a todo custo que pode pôr em risco aquilo que a tradição e o cultivo concedem ao artista: o gosto ${ }^{11}$.

O gosto, como diz nosso autor, o sentimento capaz de distinguir "a beleza entre defeitos e um defeito no meio da beleza" não pode se constituir no isolamento. Enquanto o gênio tem algo de inexplicável, um dom divino, algo de único e incomunicável, o gosto tem de ser desenvolvido e aperfeiçoado na comunicação entre os homens. O gosto intelectual, mais do que o gosto sensual, precisa "do hábito para se formar", ele é fruto do cultivo.

A relação entre o surgimento do gênio e uma sociedade com pouca liberdade parece então complexa. Ao mesmo tempo em que a influência da diferença específica e da inventividade do

11 "O gosto pode se estragar numa nação; esse mal vem ordinariamente após os séculos de perfeição. Os artistas, temendo ser imitadores, buscam rotas afastadas, distanciam-se da bela natureza, que seus predecessores captaram: há mérito em seus esforços, esse mérito encobre suas falhas. O público, que gosta de novidades, corre atrás deles, decepciona-se, e aparecem outros que fazem novos esforços para agradar; estes distanciam-se da natureza ainda mais que os primeiros: o gosto se perde; e nos encontramos rodeados de novidades que são rapidamente apagadas umas pelas outras; [...]" (Ibid.). 
gênio, do desejo de se destacar, se estabelece e repercute, pondo em risco o gosto da nação com o atrativo do novo, o cerceamento da liberdade contribui para a hipertrofia da imaginação genial. A sociedade, o comércio entre os homens e a liberdade lapidam o gosto de uma nação e controlam a imaginação do gênio' ${ }^{12}$. A ampliação da liberdade lapida o gosto, e se manifesta, por exemplo, na poesia, pois ela "será diferente entre o povo que trancafia as mulheres, e aquele que concede a elas uma liberdade sem limites".

Explorando um pouco mais a transposição das considerações que Voltaire tece sobre as artes para a filosofia, transposição respaldada pelos termos que Voltaire utiliza para se referir a Descartes e a suas obras (gênio, romance, fábula), vemos que a falta de liberdade, como na França que perseguiu Descartes, se reflete na razão isolada e apartada do mundo presente no dogmatismo dos sistemas. Já um ambiente livre como o da Inglaterra de Newton e Locke se reflete na relação que estes autores têm com o passado. É isto que diferencia a filosofia experimental da filosofia de sistema, a primeira traça uma história e se enriquece com ela, a segunda nega a história e faz um "romance" ao pretender avançar um saber todo novo.

Um gênio como Descartes, uma inteligência isolada e perseguida, distante da experiência do século que o sucedeu ${ }^{13}$, teve sua imaginação hipertrofiada pela ausência de liberdade. Daí não ter sido capaz de reconhecer a desmedida da pretensão de inteligência completa do mundo ${ }^{14}$. Ao contrário da prática da filosofia

12 "Quando há pouca sociedade, o espírito se estreita, torna-se menos penetrante, não há do que se formar o gosto " (Ibid.).

13 "Com efeito, deve-se confessar que, por mais que ele fosse um grande gênio, ainda sabia pouca coisa da verdadeira filosofia: faltava-lhe a experiência do século que se seguiu. Este século é tão superior a Descartes quanto Descartes é superior à Antiguidade" (Id., 1996, 71).

14 Sobre esta pretensão considere-se as palavras de René Pomeau: "Por que ele despreza assim tão amargamente Descartes e os cartesianos, que foram filósofos de outra envergadura comparados a Locke? É que Descartes construiu a matemática universal. 
inglesa, já presente na maneira de Locke de conceber o procedimento e o lugar da filosofia, os gênios não pensam em termos de comunidade de conhecimento.

A diferença entre as metáforas do filósofo e da filosofia de Descartes e Locke já antecipava a oposição entre estas duas perspectivas. O filósofo cartesiano é um arquiteto - engenheiro, ele estabelece todo o edifício do saber, mesmo que de fato seja impossível, de direito ele pode construir tal edifício de seus alicerces até seus últimos andares. As construções, diz Descartes, arranjadas por um só homem são mais bem acabadas do que aquelas realizadas por diversas mãos (Descartes, 1979, p. 34). Já o filósofo lockeano se apresenta como um operário (under labourer), para ele a filosofia não se constitui mais no isolamento, ela não pretende construir todo o edifício do saber, ela apenas prepara o terreno para que o edifício seja construído pelo esforço conjunto de diversas mãos, sua tarefa é limpar o caminho dos obstáculos que impedem o acesso ao conhecimento; passamos do artesanato à manufatura, do saber constituído por um só ao saber que progride com o esforço coletivo ${ }^{15}$.

$\mathrm{Na}$ Inglaterra, em filosofia, o gênio se pautou pelo gosto. Num país como a França, onde a intolerância e a falta de liberdade impedem o livre desenvolvimento da ciência, o gênio se perde numa imaginação desregrada, que, talvez, só encontre refúgio na arte. Newton só poderia ser inglês e filho de seu tempo.

Ora, se o elogio a Newton é o elogio a todo um tempo e lugar,

Leibniz construiu um universo com mônadas. Esta confiança exaspera Voltaire. Ele se sente provocado pela ingenuidade satisfeita daqueles que se iludem com suas imaginações" (Pomeau, 1974, 212).

15 "The common-wealth of learning is not at this time without master-builders, whose mighty designs in advancing the sciences will leave lasting monuments to the admiration of posterity; but everyone must not hope to be a Boyle or a Sydenham; and in an age that produces such masters as the great Huygenius, and the incomparable Mr. Newton, with some other of that strain, it is ambition enough to be employed as an under-labourer in clearing the ground a little, and removing some of the rubbish that lies in the way to knowledge [...]" (Locke, An essay concerning human understanding. Epistle to the Reader). 
a Inglaterra pós guerras civis e religiosas, e não apenas a superioridade individual do inglês sobre Descartes, como entender que o século XVII seja o século de Luís XIV? A bem da verdade, o que devemos reconhecer é que assim como sob a figura de Newton encontramos uma história das contendas científicas modernas, sob a figura de Luís XIV encontramos uma história do século XVII que está longe de ser o tradicional panegírico dos reis. Neste momento, refletir sobre o lugar da França e da Inglaterra no quadro geral das artes e ciências do século XVII nos ajudaria a compreender melhor um dos usos das categorias de gênio e gosto e o tipo de história feita por Voltaire.

\section{Século de Luís XIV ou século dos ingleses?}

\section{"Os ingleses parecem ter nascido para nos ensinar a pensar."}

A obra O Século de Luís XIV, escrita em 1752, já lidava com as categorias de gênio e gosto que encontramos bem delineadas nos verbetes das Questões sobre a Enciclopédia. Como dissemos, a análise sobre o gênio e o gosto pressupõe que possamos transferir categorias que Voltaire utiliza para as artes (notadamente nos verbetes este é o uso)para as ciências. Os verbetes gênio e gosto pareciam ter em vista mais Corneille e Racine do que Descartes e Newton. Mas é certo que os textos de Voltaire parecem permitir essa mudança de registro, afinal de contas, os elementos que caracterizam o gênio (a invenção, a imaginação e a independência), de um lado, e aqueles do gosto (o aprendizado, o tempo e o cultivo do passado), de outro, são os mesmos que caracterizam e organizam a oposição entre o cartesianismo e a filosofia experimental, ou melhor, o romance dos sistemas e a sã filosofia.

O Século de Luís XIV nos ajuda a compreender melhor esta oposição e seu caráter histórico. A primeira questão que é preciso enfrentar é a seguinte: como ficaria o século do rei-sol perante a 
defesa da Inglaterra como o berço da filosofia experimental, bem como o país em que ela chegou ao seu ápice? Não seria, como sugere o próprio autor, o século de Luís XIV, na verdade, o século dos ingleses? Qual é comparativamente o lugar da França e o da Inglaterra neste quadro geral das artes e das ciências do século XVII e início do XVIII?

A impressão que temos com a leitura do prefácio do Século de Luís XIV é que a França do XVII é incomparável. Nas quatro eras em que o gosto distingue a grandeza no meio da barbárie, Grécia, Roma, Itália renascentista e o século XVII, o século de Luís XIV aparece como aquele tempo que soube se "enriquecer das descobertas dos três outros" e fazer mais "em certos gêneros do que os três juntos"16. Toda a "Europa deve sua polidez e seu espírito de sociedade à corte de Luís XIV". Mesmo que as artes não tenham sido levadas muito mais longe do que na Itália renascentista, "a razão humana em geral se aperfeiçoou” e a sã filosofia foi conhecida nessa época. Dentro das quatro eras, só a de Luís XIV conheceu a filosofia experimental, uma estranha na Itália, por exemplo, até ser instituída por Galileu e cultivada por Torricelli. Ora, mas não é a sã filosofia, de acordo com o que vínhamos dizendo até agora, um fruto da Inglaterra? Voltaire quer dizer que Newton, legatário da atitude filosófica inaugurada por Bacon, foi quem descobriu não apenas alguns mistérios da natureza, organizando a pluralidade caótica dos fenômenos físicos ao remetê-los todos a uma lei; ele é também aquele que levou ao mais alto grau um procedimento filosófico, aquele que concilia a experiência e a

16 No prefácio ao Século de Luís XIV vemos como o historiador tem de ter gosto, o que significa dizer que tem de ser capaz de reconhecer o espírito de um tempo, encontrar no meio dos escombros e da violência da história algo que possa narrar como característica específica, como gênio de um povo ou de um tempo. Não acreditamos, assim, nem numa visada otimista sobre a história, nem em um inexorável plano racional que se realiza a despeito dos percalços dela. Como deixa ver o Prefácio ao Século de Luís XIV, o trabalho do historiador é a escolha no meio de guerras e sangue, no meio do caos, de um sentido que possa ser narrado, sem garantias e sem plano transcendente a organizá-lo. 
matemática, procedimento insuperável no âmbito das ciências.

Nesse sentido, o título o "Século de Luís XIV" é um símbolo, ele não pretende reduzir a escrita histórica à figura dos grandes, ao contrário, a obra se vale dessa tradição de escrita histórica exemplar para no interior dela realizar transformações. Vejamos um pouco mais o quadro da filosofia no século XVII.

Segundo nosso autor, o início do XVII não parecia ser capaz de "tirar [a filosofia] do caos em que ela foi submersa". A inquisição em Portugal, na Espanha e na Itália, as guerras civis na França e o fanatismo do tempo de Cronwell, na Inglaterra, não reservavam lugar para a filosofia, um tempo cujo evento notório foi a condenação de Galileu, forçado a "pedir perdão na idade de 70 anos por ter razão”. Apesar desse terreno pouco fértil para a filosofia, "frágeis tentativas" foram pouco a pouco ganhando espaço. Bacon foi quem "mostrou de longe a rota que se poderia tomar", e foi seguido por Galileu e Torricelli.

Ao mesmo tempo Descartes surgia. Mas com ele as coisas se passam de outro modo. Enquanto Bacon, Galileu e Torricelli aparecem unidos soba perspectiva experimental, Descartes "fez o contrário do que se deveria fazer, ao invés de estudar a natureza, ele quis adivinhá-la”. No mesmo parágrafo em que Voltaire fala da aurora da sã filosofia, Descartes é apresentado como seu antípoda:

Ele era o maior geômetra de seu século; mas a geometria deixa o espírito como ela o encontra. $\mathrm{O}$ de Descartes era muito dado à invenção. $\mathrm{O}$ maior dos matemáticos fez apenas romances de filosofia. Um homem que desdenhava os experimentos, que jamais citou Galileu, que desejava construir sem materiais, não poderia construir senão um edifício imaginário (Ibid., cap. XXXI (grifos nossos)).

Uma filosofia que deseja construir sozinha todo o edifício do saber sem a ajuda da observação, da história e de outros homens só pode constituir um edifico imaginário. O retrato de Descartes 
oferecido n'O Século de Luís XIV aparece novamente como seu valor ambíguo, ele é grande geômetra e filósofo metódico, opôs-se aos erros da antiguidade, substituindo-os pelas suas fantasias. Contudo, do embate dessas duas fábulas a sã filosofia se nutriu: "Já era muito destruir as quimeras do peripatetismo, ainda que por outras quimeras. Esses dois fantasmas se combateram. Caíram um após o outro, e a razão enfim se ergueu de suas ruínas" (Voltaire, 1996, cap. XXXI).

O grande problema de Descartes se encontra em sua imaginação desregrada, a característica que define o "raro talento" e o espírito de invenção. O gênio é justamente aquele que constrói sem materiais, mas isto só pode dar bons frutos nas artes, e se mesmo nelas o gênio deve se pautar pelo gosto, a história e a tradição lapidar a natureza, nas ciências a história é ainda mais importante.

Descartes desconhece os limites do esforço individual na ciência. É por esta razão que Voltaire, no mesmo parágrafo supracitado, completa sua crítica ao mau uso da imaginação por Descartes opondo ao filósofo não uma outra teoria, ou outro método, mas o relato da existência de uma academia de experiências estabelecida por Lorenzo de Médici no ano de 1655 em Florença. ${ }^{17}$ Este relato vem realçar dois aspectos que escapam à filosofia de Descartes: (1) a valorização da observação da natureza e, ainda mais importante, (2) a observação empreendida por diversos homens unidos por uma instituição científica ${ }^{18}$.

17 Talvez esteja aqui um verdadeiro ponto de aproximação entre Voltaire e Bacon, pois o avanço das ciências está ligado ao desenvolvimento das instituições da sociedade. Sobre a perspectiva baconiana, Maria das Graças de Souza diz: "Para Bacon, portanto, o progresso das ciências está associado ao desenvolvimento institucional, a decisões políticas, a um desenvolvimento do ponto de vista dos interesses e mesmo a uma certa mudança nas opiniões a respeito do lugar que o conhecimento deve ocupar na vida dos homens" (Graças de Souza, 2001, p. 31).

18 "Já se percebia, nesta pátria das artes, que não poderíamos compreender algo do grande edifíco da natureza a não ser examinando-o peça por peça. Esta academia, após os dias de Galileu, e desde Torricelli tem prestado grandes serviços" (Voltaire, 1996, cap. XXXI). No entanto, cabe lembrar que Voltaire não faz depender toda a ciência e principalmente as descobertas e invenções da atividade das academias. Na vigésima quarta carta das Cartas Filosóficas, Voltaire relativiza a importância das Academias, 
Examinar o edifício da natureza peça a peça exige a instituição de um estabelecimento como aquele favorecido por Lorenzo de Médici, é preciso uma associação de cientistas para que se possa pouco a pouco levantar o véu que encobre a natureza. Como já dizia a introdução da obra, o grande século de Luís XIV só pode nascer depois do "estabelecimento da Academia francesa", e o mais admirável é segundo o autor a ampliação da comunicação entre os sábios por meio de cartas e pela proliferação de periódicos científicos. Ora, é justamente isto que aconteceu na Inglaterra no que concerne às ciências, a despeito da administração de Cronwell. Alguns filósofos se reuniram e estabeleceram uma sociedade de sábios que posteriormente seria apoiada pelo rei Charles II. Procurando "buscar em paz verdades, enquanto o fanatismo oprimia toda verdade" esses homens ofereceram à glória de seu país os frutos de uma associação livre entre sábios. Sob este aspecto, o século de Luís XIV é o século dos ingleses. Não é, portanto, a figura do monarca e de sua vida o importante desta história ${ }^{19}$.

O caso inglês serve de exemplo e êmulo para o estabelecimento na França de instituições semelhantes. A Academia de Ciências francesa criada por Colbert em 1666 inaugura algo nunca antes visto na França: uma comunidade de sábios que partilham seus conhecimentos e suas descobertas. ${ }^{20} \mathrm{~A}$ geografia, as expedi-

afirmando que boa parte das invenções foram feitas nos séculos bárbaros e mais ou menos por acaso. Além de complexificar a relação entre o avanço do saber e as instituições, mostrando que não se trata de uma relação de causa e efeito, Voltaire afirma a necessidade das academias mais para fomentar e desenvolver a ciência do que para criar grandes cientistas e fazer novas grandes descobertas : as academias mais continuam e mantêm do que criam. Ainda assim, vemos como as noções de gênio (criação e invenção) e gosto (regras e cultivo) ajudam a compreender esta relação.

19 Sobre os resultados dessa associação criada na Inglaterra, Voltaire diz: "É de seu seio que saíram, nos nossos dias, as descobertas sobre a luz, sobre o princípio de gravitação, sobre a aberração das estrelas fixas, sobre a geometria transcendente, e cem outras invenções, que poderiam, a esse respeito, fazer com que se chamasse esse século o século dos Ingleses, assim como aquele de Luís XIV" (Voltaire, 1966, cap. XXXI). $20 \mathrm{E}$ o abandono dos sistemas contribui para o progresso do conhecimento : "Adquire-se pouco a pouco conhecimentos de todas as partes da verdadeira física, rejeitando todo sistema" (Voltaire, 1966, cap. XXXI). 
ções científicas, os jornais, as artes e o "espírito de sabedoria e de crítica" se desenvolvem. Mesmo incapaz de impedir "os furores dos fanáticos" tudo isso alargou os conhecimentos e diminuiu os efeitos da superstição.

Entretanto, as luzes da filosofia vêm da Inglaterra. Apesar do grande geômetra que foi Descartes, a filosofia francesa só tardiamente consegue se separar da filosofia de sistema. Descartes foi um gênio, cujo espírito de invenção não pôde fazer avançar a filosofia na mesma proporção de uma livre associação entre homens. Esta entrada tardia da França no caminho da sã filosofia é importante, mas lhe concede um lugar não tão glorioso na história das ciências:

A sã filosofia não fez na França tantos progressos como na Inglaterra e em Florença; e se a Academia de ciências rendeu serviços ao espírito humano, ela não colocou a França acima das outras nações. Todas as grandes invenções e as grandes verdades vêm de alhures (Voltaire, 1966, cap. XXXI $)^{21}$.

Contudo, se no que concerne à filosofia natural a França teve de aprender com os demais países, a mesma coisa não se passa com as artes. Na poesia, na eloquência, na literatura, nos livros de moral e naqueles agradáveis, os franceses foram os legisladores da Europa. Entretanto, a grandeza das artes francesas vista de perto ao mesmo tempo confirma e complexifica a relação entre gênio e gosto.

21 Em carta a Frederico de 27 de maio de 1737, Voltaire faz um diagnóstico semelhante sobre o estado das ciências na França, criticando o atraso da Universidade francesa e ressaltando a insularidade dos sábios franceses da Academia de ciências de Paris: "A respeito de nossas universidades, elas não têm outro mérito a não ser sua antiguidade. Os franceses não têm um Wolff, um Mac-Laurin, um Manfredi, um S'Gravesande, nem um Musschenbroeck. Nossos professores de física, na maioria, não são dignos de serem estudantes destes que acabo de citar. A academia de ciências sustenta muito bem a honra da nação, mas é uma luz que ainda não se espalha muito amplamente; cada acadêmico se limita a perspectivas particulares. Não temos nem boa física, nem bons princípios de astronomia para instruir a juventude; somos obrigados para isto a recorrer aos estrangeiros". 
Segundo Voltaire, as Provinciais de Pascal, as Máximas de La Rochefoucauld, os Discursos sobre a História Universal de Bossuet, Telêmaco de Fénelon, os Caracteres de La Bruyère, A Pluralidade dos Mundos de Fontenelle, o Dicionário de Bayle, Cinna de Corneille são obras que fazem a glória da França. A grandeza das artes no XVII francês parece ser incomparável, a ponto de Voltaire recordá-lo nostalgicamente ${ }^{22}$.

O século em que as artes receberam a proteção de Luís XIV é no entanto, um século de gênios. Trata-se de um século povoado de individualidades criativas e originais. Todas aquelas obras tão distintas contêm o caráter original do gênio, todas partilham a criatividade dos gestos inaugurais. As Provinciais de Pascal pertencem à “época da fixação da língua”, Bossuet inventou algo novo quando "aplicou a arte da oratória à própria história, que parecia excluí-la”, Telêmaco de Fénelon e os Caracteres de La Bruyère são obras que não encontram modelo no passado, bem como o Dicionário de Bayle. Fontenelle também não deixou de inovar, pois “a arte delicada de levar a graça até a filosofia foi também uma coisa nova".É este o gênio (singularidade, caráter específico) da França de Luís XIV: a criatividade e originalidade de seus artistas.

Todos os outros escritos dos quais falámos parecem ser de uma criação nova. É isto sobretudo que distingue esse tempo ilustre; pois eruditos e comentadores, o século XVI e o século XVII produziram muitos, mas o verdadeiro gênio não havia se desenvolvido em nenhum gênero (Ibid., cap. XXXII) 23 .

Sobretudo na literatura, os franceses inovaram. Mas a genia-

22 “ Este tempo não se encontra mais, quando um duque de La Rochefoucauld, autor das Máximas, ao sair da conversação com um Pascal ou um Arnauld, ia ao teatro de Corneille" (Voltaire, 1966, cap. XXXI).

$23 \mathrm{O}$ mais importante parece ser, no entanto, o estabelecimento na Europa do século XVII de uma comunicação entre os sábios nunca antes vista. Os matemáticos de todos os países se enviavam problemas a serem resolvidos, e a Europa viu nascer uma república literária, nenhuma "correspondência entre os filósofos foi mais universal". 
lidade deixada a si mesma não pode perdurar. Como vimos anteriormente, os gênios são importantes para o início das artes, mas o desejo de inovação não pode perdurar, "on est réduit ou à imiter ou à s'égarer".

Precisamente porque são inventores, os gênios se enganam. Este é o caso de Corneille. Sua grande obra foi Cinna, e não Cid, já que esta seria uma imitação de uma história espanhola, ao passo que Cinna é toda nova. Apesar dessa grande obra, há diversas peças indignas dele, pois "é o privilégio do verdadeiro gênio, $[. .$. cometer impunimente grandes erros”.

A mesma impunidade que se aplica aos erros de Shakespeare, a mesma ambiguidade do gênio inglês atribuída a Corneille. O francês tem a independência característica dos gênios, ele é criador e original. É aqui que Racine se distingue de Corneille. Diferentemente deste último, Racine é resultado da história, das grandes obras do passado e das vantagens de seu presente ${ }^{24}$. A oposição entre Corneille e Racine ilustra muito bem as tensões entre gênio e gosto. Racine não tem erros, suas obras são sempre elegantes e corretas. Como dissemos, a superioridade de Racine reside no fato de que ele é o resultado de toda uma sociedade e do processo da história, enquanto Corneille deve sua grandeza à sua imaginação, ao seu talento original; Newton é Racine, Descartes é Corneille, ou, se inglês, Shakespeare.

Quando se trata das artes, da literatura e da eloquência, a França tem gênios inigualáveis, mas em filosofia“ os ingleses foram mestres das outras nações" justamente porque evitaram os sistemas que se fundam na genialidade na imaginação sem regras de seus autores ${ }^{25}$. Além disso, os ingleses foram grandes por-

24 “Corneille se formou sozinho; mas Luís XIV, Colbert, Sófocles e Eurípedes contribuíram todos a formar Racine". (Voltaire, 1966, cap. XXXII).

25 "É sobretudo em filosofia que os Ingleses foram mestres das outras nações. Não se tratava mais de sistemas engenhosos (systèmes ingénieux). As fábulas dos gregos deveriam ter desaparecido há muito tempo, e as fábulas dos modernos deveriam nunca ter surgido. O chanceler Bacon tinha começadopor dizer que era preciso interrogar a 
que souberam superar a sua insularidade. "Separados do resto do mundo", eles pareciam condenados à ignorância, mas foram capazes de adquirir um enorme conhecimento sobre a antiguidade e outras nações como o Egito, a Pérsia e a Arábia. Tudo após a superação deum tempo em que as querelas religiosas perturbavam o reino.

Já Descartes, lembremos, nasceu quase poeta, dirá Voltaire, denunciando o avanço indevido da imaginação criativa, que tem lugar nas artes, sobre o campo da filosofia. As artes, mesmo que tenham também seus limites, têm um espaço para a criatividade individual que não encontramos nas ciências, concebidas sobretudo como atividade coletiva: a observação da natureza é fruto do trabalho e da comunicação entre sábios, e não da imaginação de um autor ${ }^{26}$.

\section{A visada histórica e a filosofia experimental}

Acompanhando obras tão distintas como O Século de Luís $\mathrm{XIV}$, os Elementos da Filosofia de Newton, os verbetes do Dicionário filosófico e das Questões sobre a Enciclopédia e o quase desconhecido Singularités de la nature, entre tantas outras obras, percebemos que Voltaire traça uma história da filosofia, uma história dos saberes ou uma história das questões filosóficas e suas soluções que parece ter dois planos. Um plano negativo, por meio do qual são apresentados os erros de todos os tempos, e um outro

natureza de uma maneira nova, que era preciso realizar experimentos : Boyle passou a vida a realizá-los. Aqui não é o lugar para uma dissertação em física; basta dizer que após três mil anos de buscas vãs, Newton foi o primeiro a descobrir e a demonstrar a grande lei da natureza por meio da qual todos os elementos da matéria se atraem reciprocamente, lei por meio da qual todos os astros se mantêm em seus cursos. Ele foi o primeiro a ver de fato a luz; antes dele, não a conhecíamos. (Ibid., cap. XXXIV (grifos nossos))

26 Isto se coaduna com a interpretação voltairiana do lema newtoniano hypotheses non fingo, cujo sentido pretende evitar o caráter demasiado inventivo das suposições no âmbito das ciências. 
plano positivo, em que vemos nascer e se desenvolver a filosofia experimental.

Todas as questões filosóficas são tratadas a partir de uma mise-en-scène que expõe o conflito das filosofias. Mas esse conflito, que poderia ser apenas a tradicional exposição cética da diafonia filosófica, ganha um sentido histórico e filosófico quando atinamos para o lugar ocupado pela filosofia experimental e, principalmente, por Newton. A narrativa da história da filosofia deixa de ser uma oposição de teses e argumentos sem resultado positivo para se transformar em visada histórica da filosofia, em que certos conhecimentos avançam lentamente com a instauração de um novo procedimento filosófico inaugurado por Bacon.

Em outras palavras, Voltaire se afasta dos termos do cartesianismo ao elaborar uma história da filosofia. Não o faria caso ela tivesse somente seu lado negativo, a história stultitiae. Sabemos que a história não tem lugar no quadro teórico do cartesianis$\mathrm{mo}^{27}$, de acordo com o qual recensear as posições filosóficas da antiguidade até a modernidade não passaria, de acordo com a perspectiva cartesiana, de narrar a história dos erros e da estupidez humana. Nesse sentido, o primeiro plano da narrativa histórica de Voltaire, aquele que narra a diaphonia das filosofias, retoma a posição segundo a qual para a verdade só há um caminho enquanto os desvios são muitos, de modo que a história dos conflitos das seitas filosóficas só pode ser a história dos iludidos. Se a verdade tivesse se manifestado em algum dos sistemas con-

${ }_{27}$ Carlos Alberto Ribeiro de Moura, História Stultitiae e História Sapientiae. In: Racionalidade e Crise: estudos de história da filosofia moderna e contemporânea. Discurso Editorial e Editora UFPR. São Paulo/Curitiba, 2001. A recusa cartesiana da história é apresentada nos seguintes termos: "Porque, para Descartes, a relação da filosofia com sua história só poderá ser de oposição integral. O que fará com que, caso haja uma história da filosofia, essa só possa ser vista como uma história stultitiae, já que a descoberta da verdadeira filosofia terá como consequência a volatilização do passado filosófico. Agora, a certeza racional e matemática deve eliminar a controvérsia e a diversidade das filosofias, já que a verdade é uma e apenas o erro é múltiplo. E a história da filosofia será rejeitada em nome da incerteza fundamental que revela a controvérsia sem fim entre as seitas" (op. cit. p. 23). 
flitantes, o conflito mesmo deixaria de existir (Descartes, 1989, p. 15).

Contudo, nesse quadro histórico da filosofia, a história stultitiae tem um limite: a filosofia experimental surgida na Inglaterra. A partir daí é possível narrar outra história, não mais aquela dos sistemas que se anulam mutuamente, sistemas fundados sobre o gênio de seus autores, que pertencem a história dos erros, mas a história do nascimento e desenvolvimento da sã filosofia, do primado do gosto, do procedimento que agora permitirá que o conhecimento avance pouco a pouco, e não de um saber que sempre recomeça. Não se trata, então, de mera doxografia, pois o advento da filosofia experimental torna o trabalho do historiador da filosofia não apenas o relato de opiniões diversas, mas permite uma história filosófica da filosofia. $\mathrm{O}$ advento da filosofia experimental impede, por conseguinte, que o filósofo, perante a supostamente interminável disputa entre as seitas, se entregue à condição preguiçosa da suspensão do juízo e da negação da filosofia. Mais do que isso, podemos afirmar, não sem alguma temeridade, que a importância da história, conhecidamente um objeto de reflexão do patriarca de Ferney, significa também que Voltaire não só fazia dela objeto de reflexão filosófica, como transformava a filosofia em um trabalho histórico. Em outras palavras, Voltaire concede um valor filosófico à história dos saberes na medida em que todas as questões que importam aos homens, todos os problemas filosóficos, demandam uma visada histórica caracterizada pelo jogo de oposição das diversas perspectivas oferecidas pela variedade das doutrinas filosóficas. Mas a variedade conflituosa não condena toda a história da filosofia, a divisão entre os romances, fábulas e sistemas dos antigos e dos modernos, de um lado, e a sã filosofia inaugurada por Bacon e levada a cabo por Newton, de outro, entre gênio e gosto, permite que o philosophe organize essa historia de modo bem particular, evitando que a diafonia filosófica conduza à suspensão do juízo. A ideia de progresso tanto comentada nos autores do XVIII exigiu uma mudança na própria 
filosofia, que agora se torna ela também histórica. Numa palavra, a filosofia da história ao mesmo tempo permite e exige uma história da filosofia.

Portanto, é preciso reconhecer a centralidade da história no pensamento de nosso autor, centralidade dependente das várias acepções do termo: a história no seu sentido aristotélico e lockeano de coleta e recenseamento dos dados da experiência(observação), a história como consideração dos costumes e do passado (gosto, cultivo e comunicação) e a história como processo cumulativo (progresso). O primeiro sentido é o que caracteriza o procedimento da filosofia experimental que tanto Voltaire elogia ${ }^{28}$, e que garante o sucesso desta postura filosófica, sucesso que se complementa com a segunda acepção do termo, pois, além da observação dos fenômenos, costumes livres e uma relação rica com o passado e com o seu próprio tempo lapidam uma imaginação que sem isto se desgarraria. Por fim, estes dois sentidos de história se completam com a terceira acepção, pois o sucesso da filosofia experimental, cujo sentido só é apropriadamente compreendido ao atinarmos para os dois primeiros sentidos do termo, faz com que a história da filosofia não seja considerada como um conflito interminável de seitas cujas teses e argumentos se equivaleriam, do conflito surge um procedimento filosófico que faz o saber progredir e não uma filosofia de começos eternos.

\section{Bibliografia}

MARTIN-HAAG, E. Voltaire: du cartésianisme aux Lumières. Paris, Vrin, 2002.

28 Lembremos que o próprio Locke caracteriza seu método como simples e histórico (plain and historical). 
POMEAU, R. La Religion de Voltaire. Paris, Librarie Nizet, 1974.

SPITZER, L. Études de style. Paris, Gallimard, 1970.

VOLTAIRE. Cartas Inglesas. In Os Pensadores. São Paulo, Abril Cultural, 1973 .

. Questions sur l'Encyclopédie par des amateurs. Sixième partie, 1771.

- Elementos da Filosofia de Newton. Trad. Maria das Graças de Souza. Campinas, Ed. Unicamp, 1996.

. Le Siècle de Louis XIV. Paris, Garnier-Flammarion, 1966. 
